\title{
MSH6 wt Allele
}

National Cancer Institute

\section{Source}

National Cancer Institute. MSH6 wt Allele. NCI Thesaurus. Code C50998.

Human MSH6 wild-type allele is located within 2p16 and is approximately $24 \mathrm{~kb}$ in length.

This allele, which encodes DNA mismatch repair protein MSH6, plays a role in DNA

mismatch repair. Aberrant alleles are associated with colon, endometrial and stomach cancers. 